\title{
SLAVIC STUDIES
}

\section{Gorbachev's Struggle for Economic Reform \\ Anders Åslund}

"There is no better, more politically sophisticated account of Mr. Gorbachev's economic program and the obstacles that stand in its way." -New York Times Book Review. Studies in Soviet History and Society.

$\$ 12.95$ paper, $\$ 38.50$ cloth

\section{Sex and Society in the World of the \\ Orthodox Slavs, 900-1700}

\section{Eve Levin}

In this pioneering book, Levin explores the tensions between church precepts and actual sexual behavior among the peoples of Serbia, Bulgaria, and Russia from their conversion to Christianity in the ninth and tenth centuries until the end of the seventeenth century. $\$ 29.95$

\section{Russia Goes to the Polls \\ The Election to the All-Russian \\ Constituent Assembly, 1917 \\ Oliver H. Radkey}

Foreword by Sheila Fitzpatrick. "A pioneering effort, this endeavor is on the cutting edge of today's historical research, where historians begin to look not only at the major political parties but also at specific interest groups. The new data in this book will immediately become the standard reference for any discussion of popular attitudes and political parties or social trends during the Russian revolution." -Vladimir Brovkin, Oberlin College $\$ 24.50$

\section{Soldiers in the Proletarian Dictatorship}

The Red Army and the Soviet Socialist

State, 1917-1930

Mark von Hagen

"This is the first study of the Red Army as an institution of socialization; it also tells the story of the political and social struggles within the army through the 1920s in greater detail than has hitherto been explored. There simply is no other book like this in the field."-Ronald Grigor Suny, University of Michigan, Ann Arbor. Studies in Soviet History and Society. Studies of the Harriman Institute. $\$ 29.95$ The Soviet Union and the Politics of Nuclear Weapons in Europe, 1969-1987

\section{Jonathan Haslam}

Bringing together extensive research among Soviet, West European, and American sources, Haslam provides a provocative analysis of the evolution of Soviet foreign and defense policies from Brezhnev to Gorbachev. \$13.95 paper, \$34.95 cloth

\section{Renaissance Culture in Poland} The Rise of Humanism, 1470-1543 Harold B. Segel

This is the first book-length account of Renaissance humanism in 15 th- and 16 thcentury Poland. Segel demonstrates that a lively community of intellectuals-Copernicus among them-helped to bring Poland into the mainstream of contemporary European culture and to lay the foundations for the Polish High Renaissance of the second half of the sixteenth century. $\$ 34.50$

At bookstores, or call 800-666-2211 (credit card orders only)

\section{Cornell University Press}

124 Roberts Place, Ithaca, NY 14850 


\section{IN FORTHCOMING ISSUES}

Michael Mikos, "New Light on the Relationship between Henryk Sienkiewicz and Jeremiah Curtin"

Daniel Rancour-LaFerriere, "From Incompetence to Satire: Voinovich's Image of Stalin as Castrated Leader of the Soviet Union in 1941"

Ronald W. Vroon, "Aleksei Kruchenykh's 'Razboinik Van'ka Kain' and the Literary Politics of $L E F$ "

Ellen Chances, “Andrei Bitov's 'Life in Windy Weather': The Creative Process in Life and Literature"

Irene G. Gross, "The Tangled Tradition: Custine, Herberstein, Karamzin, and the Critique of Russia"

\section{TO THOSE WISHING TO SUBMIT MANUSCRIPTS}

Manuscripts for consideration should be submitted in four double-spaced typed copies. (If manuscripts are computer generated, they should be letter quality or near letter quality. Continuous form sheets must be separated.) Notes and block quotations should be double-spaced; notes should be placed at the end of the manuscript and not at the bottoms of pages. Figures, charts, photographs, and other illustrative materials must be available in cameraready form, although camera-ready copy does not have to be sent with the initial submission.

Manuscripts are sent to outside readers in anonymous form and should be prepared accordingly. Library of Congress transliteration and the Chicago Manual of Style are to be followed. In general, articles should not exceed twentyfive typed pages $81 / 2^{\prime \prime}$ and $11^{\prime \prime}$ in dimension-including endnotes. Manuscripts will not be returned unless postage is included; please do not send checks.

The policy of the Slavic Review is not to consider materials that have been published or that are being considered for publication elsewhere.

Publication of articles in the Slavic Review is ordinarily limited to those submitted by members of AAASS. Nonmembers wishing to submit manuscripts are asked to request a membership application; please see the inside front cover for information on membership. 


\title{
H. B. Paksoy \\ ALPAMYSH: CENTRAL ASIAN IDENTITY UNDER RUSSIAN RULE
}

\author{
(Hartford, CT: Association for the Advancement of Central Asian Research) \\ (Paperback) \$10.95; (Hardcover) $\$ 49.95+\$ 2.50 \mathrm{S \& H}$ \\ Prepayment required from individual purchasers \\ ORDERS: Treasurer, AACAR, Department of History, UMASS-Amherst, \\ MA 01003 \\ or, Booksellers
}

Paksoy... is absolutely right about the value of the oral, "folk" records like the dastans for preserving ethnic identity... I am also impressed by Paksoy's insistence (contra a rash of superficial contentions recently) that a fundamental unity of Turks persists across all artificial Soviet divisions, without, however, necessarily having political implications.

John A. Armstrong - Emeritus, University of Wisconsin-Madison

It's an impressive achievement and a valuable contribution to an area which has rarely received such meticulous examination as Dr. Paksoy has carried out.

\section{Muriel Atkin - The George Washington University}

I have only the highest praise for its scholarship. It combines a solid examination of the dastan with an illuminating case study of the importance of the collective memory for the maintenance of ethnic and community identity.

Keith Hitchins - University of Illinois, Urbana-Champaign

This is one of those rare books which offer the Western reader a Central Asian perspective on the Russian conquest of the non-Slavic territories in Asia. I found Professor Paksoy's translation and commentary on Alpamysh to be informative and inspiring.

Ewa M. Thompson - Rice University

Dr. Paksoy has done a beautiful job with the dastan Alpamysh. The work is meticulously and exactingly done, and presented clearly.

Wayne S. Vucinich - Stanford University 